\title{
A practical approach to the patient with acquired haemophilia A in Poland
}

\author{
Magdalena Górska-Kosicka1® ${ }^{1}$, Michał Wójciak ${ }^{2}$, Jerzy Windyga ${ }^{1,3 \odot}$ \\ ${ }^{1}$ Department of Disorders of Hemostasis and Internal Diseases, Institute of Hematology and Transfusion \\ Medicine in Warsaw \\ ${ }^{2}$ Faculty of Medicine, Medical University of Warsaw \\ ${ }^{3}$ Department of Hemostasis and Metabolic Diseases, Institute of Hematology and Transfusion Medicine, \\ Warsaw
}

\begin{abstract}
Summary
Acquired haemophilia (AHA) is a severe acquired bleeding disorder that develops due to circulating autoantibodies directed against coagulation factor VIII (FVIII). These antibodies inhibit the coagulation activity of FVIII in patient's plasma. AHA is mainly diagnosed in the elderly and more than half of the cases are idiopathic. Underlying conditions which favor AHA occurrence are — among others — autoimmune diseases, neoplasms, pregnancy and 12-month post-partum period. The clinical picture is dominated by extensive ecchymosis, less often by intramuscular and retroperitoneal haematomas or hemorrhages to the central nervous system. Laboratory findings include isolated prolonged activated partial thromboplastin time (APTT), decreased FVIII activity and the presence of a FVIII inhibitor. Although patients with AHA usually present with severe hemorrhagic disorders, asymptomatic forms may also occur, with accidentally detected prolonged APTT as the only abnormality. The aim of AHA management is bleeding control and eradication of inhibitor.
\end{abstract}

Key words: acquired haemophilia A, factor VIII, bypassing agents, inhibitor, bleeding

J Transf Med 2020; 13: 186-194

\section{Introduction}

Acquired haemophilia A (AHA) is a severe bleeding disorder caused by autoantibodies directed against coagulation factor VIII (factor VIII, FVIII). These antibodies, called circulating anticoagulants or inhibitors, inhibit the coagulation function of FVIII and reduce its activity in the patient's plasma [1-3]. Contrary to congenital haemophilia A due to $\mathrm{F} 8$ gene mutation on the $\mathrm{X}$ chromosome (affecting mostly males), AHA is an autoimmune disease which almost equally affects both sexes [2].

Acquired hemophilia A belongs to a category of rare diseases with annual incidence estimated at approximately 1.5/1,000,000 inhabitants. The data however may be underestimated due to misdiagnosis [2]. The incidence of AHA increases with age. According to the results of the multi-center European Acquired Hemophilia Registry (EACH2 registry) the median age at presentation is 73.9 years [4]. AHA occurs with comparable frequency in men and women with the exception of a small peak for women in the 20-40 year age group due to pregnancy and the 3 -month post-partum period $[2,5]$. AHA is sporadic in childhood; in newborns, it may be associated with transplacental passage of maternal antibodies against FVIII to the fetus $[6,7]$.

In approximately $50 \%$ of patients, the cause of AHA is unknown/cannot be identified (the disease is idiopathic). In all other cases, AHA either

Corespondence adress: Magdalena Górska-Kosicka, Department of Disorders of Hemostasis and Internal Diseases, Institute of Hematology and Transfusion Medicine, Indiry Gandhi Street 14, 02-776 Warszawa, phone 22349 61 08; e-mail: magdagorska@tlen.pl Translation: mgr Krystyna Dudziak 
coexists with autoimmune and dermatological diseases, neoplasms, pregnancy and puerperium, or is attributed to drug exposure (Table 1) $[1,2,4]$. According to the AHA-POL registry, which includes 2011-2013 data collected in four Polish haematological centres (Warsaw, Krakow, Poznan, Łódź), in 58\% of patients AHA was idiopathic, in $20 \%$ of patients AHA coexisted with autoimmune diseases, in $18 \%$ with malignancy, and in $4 \%$ it was related to pregnancy or puerperium [8].

Diagnosis of acquired haemophilia A should be considered when the patient manifests sudden, heavy bleeding with no personal and familiar history of haemorrhagic disorders. Characteristic for AHA are subcutaneous haemorrhages and large hematomas (Fig. 1) as well as compartment syndrome and compression of nerves and blood vessels. Particularly difficult to control is bleeding from post-surgical wounds therefore for AHA patients and persons suspected of AHA all invasive procedures should be avoided. On the other hand, hemarthroses so typical for inherited haemophilia A are very rare in AHA $[1,2,4]$.

\section{Diagnosis}

Clinical course of AHA is usually severe and the diagnosis is based on the clinical picture. However, asymptomatic course is also likely and the diagnosis is then confirmed by laboratory findings $[2,3,9]$.

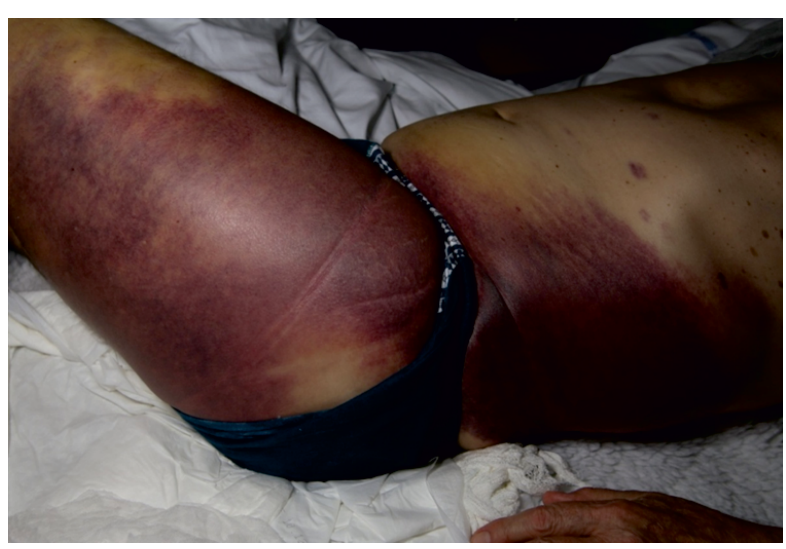

Figure 1. Subcutaneous ecchymoses typical of acquired hemophilia A (collection by M. Górska-Kosicka)

Screening coagulation laboratory tests present isolated prolonged activated partial thromboplastin time (aPTT) while prothrombin time (PT), thrombin time (TT), fibrinogen concentration and platelet count are normal. The same pattern of results is reported for inherited deficiencies of factors VIII, IX, XI, XII and lupus anticoagulant (LA). Therefore, to differentiate between the isolated factor deficiency and the presence of coagulation inhibitor it is recommended to determine APTT in a 1:1 mixture of study plasma and normal plasma (with all clotting factors). If APTT in this mixture is not normalized - i.e. the correction test is negative or circulating anticoagulant is detected — the inhibi-

Table 1. Underlying disorders and conditions predisposing to development of acquired hemophilia A (according to $[1,2,4]$, own modification)

\begin{tabular}{l}
\hline Tumors \\
\hline Hematological: chronic lymphocytic leukemia, Hodgkin's lymphoma, multiple myeloma, non-Hodgkin's lymphomas, \\
myelodysplastic syndromes, Waldenström's macroglobulinemia, primary myelofibrosis, erythroleukemia \\
Solid tumors: cancer of the lung, prostate, breast, colon, stomach, kidney, cervix, head and neck, melanoma, hepato- \\
cellular carcinoma (HCC) \\
\hline Autoimmune diseases \\
Systemic lupus erythematosus, rheumatoid arthritis, ulcerative colitis, Sjögren's syndrome, Goodpasteure's syndrome, \\
multiple sclerosis, myasthenia gravis, autoimmune haemolytic anemia, autoimmune thyroid disease \\
\hline Pregnancy and the puerperium \\
Usually up to 12 months after delivery \\
\hline Medicinal products \\
Beta-lactam antibiotics, chloramphenicol, sulfonamides, phenytoin, methyldopa, interferon alfa, depot neuroleptics \\
- thioxanthene derivatives, non-steroidal anti-inflammatory drugs, fludarabine, clopidogrel, nivolumab \\
\hline Skin diseases \\
Psoriasis, pemphigus \\
\hline Others \\
Hepatitis B and C, asthma, chronic obstructive pulmonary disease, monoclonal gammapathies of unknown significance
\end{tabular}


Table 2. Differential diagnosis of isolated prolonged aPTT (based on [2])

\begin{tabular}{|c|c|c|c|c|c|c|c|c|c|}
\hline Cause & APTT & PT & TT & $\begin{array}{l}\text { Plate- } \\
\text { lets }\end{array}$ & $\begin{array}{l}\text { Fibrin- } \\
\text { ogen }\end{array}$ & $\begin{array}{l}\text { Correction } \\
\text { test APTT* }\end{array}$ & $\begin{array}{l}\text { Inhibitor } \\
>0,5 \text { j.B./ } \\
\quad / \mathrm{ml}\end{array}$ & $\begin{array}{l}\text { Activity } \\
\text { of clotting } \\
\text { factors }\end{array}$ & Clinical picture \\
\hline $\begin{array}{l}\text { Acquired } \\
\text { haemophilia A }\end{array}$ & $\uparrow$ & $\mathrm{N}$ & $\mathrm{N}$ & $\mathrm{N}$ & $\mathrm{N}$ & No correction & $\begin{array}{c}\text { Present } \\
\text { inhibitor } \\
\text { FVIII }\end{array}$ & $\downarrow$ FVIII & $\begin{array}{l}\text { Sudden hemorr- } \\
\text { hagic disorder }\end{array}$ \\
\hline Haemophilia A & $\uparrow$ & $\mathrm{N}$ & $\mathrm{N}$ & $\mathrm{N}$ & $\mathrm{N}$ & Correction & Absent & $\downarrow F V I I I$ & $\begin{array}{l}\text { Hemorrhagic } \\
\text { disorder }\end{array}$ \\
\hline $\begin{array}{l}\text { Congenital } \\
\text { haemophilia A } \\
\text { complicated } \\
\text { by factor VIII } \\
\text { inhibitor }\end{array}$ & $\uparrow$ & $\mathrm{N}$ & $\mathrm{N}$ & $\mathrm{N}$ & $\mathrm{N}$ & No correction & $\begin{array}{c}\text { Present } \\
\text { inhibitor } \\
\text { FVIII }\end{array}$ & $\downarrow F V I I I$ & $\begin{array}{l}\text { The ineffective- } \\
\text { ness of the exis- } \\
\text { ting substitution } \\
\text { treatment }\end{array}$ \\
\hline $\begin{array}{l}\text { Von Willebrand } \\
\text { disease type } 3\end{array}$ & $\uparrow$ & $\mathrm{N}$ & $\mathrm{N}$ & $\mathrm{N}$ & $\mathrm{N}$ & Correction & Absent & $\downarrow F V I I I, \downarrow$ VWF & $\begin{array}{l}\text { Hemorrhagic } \\
\text { disorder }\end{array}$ \\
\hline Haemophilia B & $\uparrow$ & $\mathrm{N}$ & $\mathrm{N}$ & $\mathrm{N}$ & $\mathrm{N}$ & Correction & Absent & $\downarrow \mathrm{FIX}$ & $\begin{array}{l}\text { Hemorrhagic } \\
\text { disorder }\end{array}$ \\
\hline $\begin{array}{l}\text { Haemophilia B } \\
\text { complicated } \\
\text { by factor IX } \\
\text { inhibitor }\end{array}$ & $\uparrow$ & $\mathrm{N}$ & $\mathrm{N}$ & $\mathrm{N}$ & $\mathrm{N}$ & No correction & $\begin{array}{c}\text { Present } \\
\text { inhibitor } \\
\text { FVIII }\end{array}$ & $\downarrow$ FIX & $\begin{array}{l}\text { The ineffective- } \\
\text { ness of the exis- } \\
\text { ting substitution } \\
\text { treatment }\end{array}$ \\
\hline FXI deficiency & $\uparrow$ & $\mathrm{N}$ & $\mathrm{N}$ & $\mathrm{N}$ & $\mathrm{N}$ & Correction & Absent & $\downarrow F X I$ & $\begin{array}{l}\text { Hemorrhagic } \\
\text { disorder }\end{array}$ \\
\hline $\begin{array}{l}\text { FXII decifiency } \\
\text { (Hageman's } \\
\text { anomaly) }\end{array}$ & $\uparrow$ & $\mathrm{N}$ & $\mathrm{N}$ & $\mathrm{N}$ & $\mathrm{N}$ & Correction & Absent & $\downarrow F X I I$ & $\begin{array}{c}\text { No symptoms of } \\
\text { hemorrhagic } \\
\text { disorder }\end{array}$ \\
\hline $\begin{array}{l}\text { Lupus antico- } \\
\text { agulant (LA) }\end{array}$ & $\uparrow$ & $\mathrm{N}$ & $\mathrm{N}$ & $\mathrm{N}$ & $\mathrm{N}$ & No correction & Absent & $\begin{array}{l}\text { LA may } \\
\text { interfere } \\
\text { with clotting } \\
\text { factor me- } \\
\text { asurements } \\
\text { false negative } \\
\text { result }\end{array}$ & $\begin{array}{l}\text { No symptoms of } \\
\text { hemorrhagic dis- } \\
\text { order sometimes } \\
\text { thrombosis }\end{array}$ \\
\hline
\end{tabular}

* Lack of appropriate APTT correction in the 1:1 mixture of study and normal plasma points to the presence of an inhibitor (or circulating anticoagulant). APTT — activated partial thromboplastin time; PT — prothrombin time; TT — thrombin time; FIB - fibrinogen; VWF — von Willebrand factor; F - factor; LA - lupus anticoagulant; $N$ - results within reference range; $\uparrow$ result above reference range; $\downarrow$ result below reference range

tor is likely to be present, most commonly against factor VIII, other coagulation factors of the intrinsic pathway and in patients with LA $[1,2,9,10]$. LA is an antibody directed against protein-phospholipid complexes which presents no bleeding symptoms but may predispose to thrombosis [2]. Low FVIII activity (usually $0-20 \mathrm{IU} / \mathrm{dl}$ ) confirms that the circulating anticoagulant is directed against FVIII. The last stage of AHA diagnostics is titration of autoantibody (factor VIII inhibitor) in Bethestda units per milliliter (BU/ml) [1-3, 9].

It is worth mentioning here that development of FVIII inhibitor may also occur as side effect/complication of congenital haemophilia A management (unlike in AHA, the inhibitor is an alloantibody developed in response to exogenous factor VIII administered during replacement therapy). As in the case of AHA patients, the test for the presence of the inhibitor is positive, while the activity of FVIII is undetectable $(<1 \mathrm{IU} / \mathrm{dl})[2,12]$. These two diseases are differentiated primarily by the clinical picture and medical history. Differentiation of causes of isolated APTT are shown in in Table 2.

Laboratory tests for AHA should be performed on blood samples collected prior to initiation of hemostatic treatment (see below). In some patients, APTT is shortened after administration of hemostatic drugs which makes the interpretation of test results difficult and AHA may be erroneously excluded as the cause of hemorrhagic disorder [1,2].

\section{Hemostatic treatment}

Unlike in congenital haemophilia A, in AHA there is no close correlation between plasma FVIII activity and the intensity/severity of hem- 
Table 3. Medicinal products/Drugs used to control bleeding in acquired hemophilia A [based on 2, 9]

\begin{tabular}{|c|c|}
\hline Medicinal products & Dosage \\
\hline $\begin{array}{l}\text { rFVIla - first-choice drug } \\
\text { in many clinical situations }\end{array}$ & $\begin{array}{l}\geq 90 \mu \mathrm{g} / \mathrm{kg} \text { i.v. every } 2-3 \mathrm{~h} \text { for heavy bleeding; once hemostasis is achieved, intervals } \\
\text { between injections extended to } 4-6-12-24 \mathrm{~h}\end{array}$ \\
\hline aPCC & 50-100 IU/kg i.v., every 8-12 h (max. 200 IU/d) \\
\hline \multirow[t]{2}{*}{ rpFVIII } & $\begin{array}{l}\text { No anti-rpFVIII antibodies: initially 50-100 IU/kg i.v, followed by control of FVIII } \\
\text { plasma activity; }\end{array}$ \\
\hline & $\begin{array}{l}\text { Anti-rpFVIII antibodies present: initially } 200 \mathrm{IU} / \mathrm{kg} \text { i.v. for heavy bleeding or 50-100 } \\
\mathrm{IU} / \mathrm{kg} \text { i.v. for mild bleeding; then under control of FVIII plasma activity }\end{array}$ \\
\hline $\begin{array}{l}\text { Human FVIII concentrate - drug } \\
\text { with uncertain efficacy in most } \\
\text { clinical situations in the course } \\
\text { of AHA }\end{array}$ & $\begin{array}{l}50-100 \text { IU every } 8-12 \text { h or by continuous intravenous infusion under the control of } \\
\text { FVIII plasma activity }\end{array}$ \\
\hline $\begin{array}{l}\text { Desmopressin - a drug with } \\
\text { uncertain efficacy in most clinical } \\
\text { situations in the course of } A H A\end{array}$ & $\begin{array}{l}0.3-0.4 \mu \mathrm{g} / \mathrm{kg} \text { in } 30-\text { minute intravenous infusion, repeated every } 24 \mathrm{~h} \text { if necessary, } \\
\text { under the control of FVIII plasma activity }\end{array}$ \\
\hline $\begin{array}{l}\text { Tranexamic acid - as supportive } \\
\text { treatment }\end{array}$ & $1 \mathrm{~g}$ every $8 \mathrm{~h}$ i.v. or p.o. \\
\hline
\end{tabular}

orrhagic disorder. Even with a low inhibitor titer and residual FVIII activity there may occur severe, life-threatening bleeding episodes that require immediate hemostatic intervention $[1,2]$. Administration of human FVIII concentrate to an AHA patient is associated with its inactivation by anti-FVIII inhibitor and so bleeding will not be arrested. Only in very few AHA cases substitution of human factor VIII may prove effective $[2,9]$. The treatment of choice in AHA patients is therefore administration of by-passing agents (BPAs), i.e. recombinant activated factor VII(rFVIIa) and activated prothrombin complex concentrate (aPCC) which activate the clotting process and bypass the FVIII-dependent stage (bypass the FVIII inhibitor) [(Table 3) 2, 11].

Free of charge inhibitor-bypassing concentrates are available for patients with strong suspicion or confirmed diagnosis of AHA within the National Program for the Treatment of Patients with Hemophilia and Related Hemorrhagic Disorders (Ministry of Health program for 2019-2023). They are distributed by the Polish Regional Blood Transfusion Centers (RCKiK). Just as other clotting factor concentrates, the inhibitor-bypassing agents can be ordered via website https://csm-swd. nfz.gov.pl/cnr/start.htm (after entering "czynnik na ratunek" ("factor to the rescue") in the web browser). The order may be issued by any physi- cian licensed to practice medicine on the territory of the Republic of Poland.

Efficacy of inhibitor bypassing concentrates in the management of bleeding AHA patients has been confirmed by clinical trials and registry data [4, 13-17]. According to EACH2 registry, the effectiveness of rFVIIa and aPCC was comparable and estimated at $91.8 \%$ and $93.3 \%$ respectively [13]. In many clinical situations however, rFVIIa is the first line approach to management of AHA patients with severe hemorrhagic disorder [1, 2]. Small volume of the solution facilitates rapid injection. A certain drawback is the short biological half-life of rFVIIa which in massive bleeding means application every $2-3$ hours ( mild bleeding requires $4,6,8,12$ and even $24 \mathrm{~h}$ intervals). On the other hand, drug administration at short intervals provides conditions for better control of treatment and immediate modification of heavy bleeding, if necessary (the more so that the maximum daily dose of rFVIIa is unspecified).

Activated prothrombin complex concentrate $(\mathrm{aPCC})$ has a longer biological half-life, and is therefore administered every 8 hours (for severe bleeding) and every $12-24$ hours if bleeding is less intensive. The single maximum dose should not exceed $100 \mathrm{IU} / \mathrm{kg}$ body weight and the daily dose $-200 \mathrm{IU} / \mathrm{kg}$ body weight $[1-3,9,11,18]$. The lyophilisate dissolving time is longer than for 
rFVIIa therefore at the Institute of Hematology and Transfusion Medicine aPCC is frequently administered to AHA patients only after severe bleeding is controlled in order to prevent bleeding recurrence. In the event of unsatisfactory clinical response to rFVIIa, aPCC should be applied immediately. For this reason hemophilia treatment centres should have permanent access to both the BPAs.

AHA patients are at high risk of severe bleeding until the inhibitor is eradicated (see below). Long-term BPA prophylaxis should be considered for patients with persistent inhibitors and lifethreatening bleeds or recurrent bleeding episodes. In such cases aPCC is the drug of choice due to longer duration. Though not based on solid medical evidence, the legitimacy of such procedure is confirmed by the results of a prospective study published by Arokshallasi et al. [19]. No bleeding was reported for $9(81.8 \%)$ of 11 patients on aPCC prophylaxis. No side effects were observed. The BPA were administered at a standard dose of 30-60 IU/kg body weight 3 times weekly and twice a week for patients at high cardiovascular risk or difficult venous access. Prophylaxis was continued until eradication of inhibitor [1].

A potential adverse reaction of BPA therapy are thromboembolic events which may be an issue for discussion. Bypassing agents are considered strongly prohemostatic. According to EACH2 registry, thromboembolic complications (deep vein thrombosis, stroke and myocardial infarction) were observed in $4.8 \%$ of aPCC and $2.3 \%$ of rFVIIa treated patients [13]. The figures are not at all appalling considering that AHA patients are mostly elderly people (8-9 decade of life) with numerous co-morbidities, including diseases that already put them at high risk of thromboembolic complications. It is the opinion of most physicians who rely on BPAs in their daily clinical practice, that the therapy has one drawback - it cannot be monitored for efficacy in laboratory tests [2, 20].

No such drawback is associated with recombinant porcine factor VIII (rpFVIII) recently registered for AHA management. Its coagulant activity is similar to that of human FVIII, but due to difference in the structure of amino acids it is not neutralized by the autoantibodies of AHA patients to the same extent as human FVIII (see below) [21].

Effectivity of rpFVIII for management of bleeding in AHA patients was first assessed in phase II/III clinical trial, the results of which were published in 2015 and as consequence the product received marketing approval [21]. In the study, the rpFVIII initial dose was $200 \mathrm{IU} / \mathrm{kg}$ while the subsequent ones depended on the FVIII activity in patient's plasma and on his clinical condition [21]. The treatment proved fully effective in $85.7 \%$ of cases and partially effective in $14.3 \%$ [22]. Subsequent post-marketing studies confirmed the effectiveness of lower doses of the product for bleeding management in AHA [23, 24].

One important advantage of rpFVIII is the possibility of monitoring its clinical efficacy through laboratory measurements of factor VIII activity in plasma. According to product characteristics, the plasma factor VIII activity should be $>80 \mathrm{IU} / \mathrm{dl}$ for severe haemorrhages and $>50 \mathrm{IU} / \mathrm{dl}$ for milder bleedings [25].

In the plasma of AHA patients there may appear cross-reacting antibodies that neutralize human FVIII and rpFVIII. Therefore, prior to rpFVIII application the titer of anti-rpFVIII antibodies should be determined $[2,3,9]$.

If no anti-rpFVIII antibodies are detected at baseline, the rpFVIII initial dose is determined at 50-100 IU/kg [2, 3, 9] (Table 3). Subsequent doses are administered every 4-12 hours depending on rpFVIII activity in patient's plasma and the clinical picture. For patients with anti-rpFVIII antibodies, the initial rpFVIII dose is set at $50-100 \mathrm{IU} / \mathrm{kg}$ body weight for mild and moderate bleeding and at $200 \mathrm{IU} / \mathrm{kg}$ for severe bleeding. The same applies to patients with undetectable anti-rpFVIII antibodies. Subsequent dose adjustment is based on sequential measurements of FVIII activity in the patient's plasma [2, 3, 9]. As already mentioned, regardless of antibody status, the minimum activity of FVIII at the start of therapy should be $>50 \mathrm{IU} / \mathrm{dl}$ for mild bleeding, and $80 \mathrm{IU} / \mathrm{dl}$. for moderate and severe bleeding. Once the bleeding is under control, it is recommended to maintain a minimum FVIII activity of 30-40 IU/dl until the wound heals. It is worth mentioning that during rpFVIII therapy FVIII activity in the patient's blood should not exceed $200 \mathrm{IU} / \mathrm{dl}[2,26]$.

As consequence of rpFVIII therapy, the titer of anti-rpFVIII antibodies may sometimes increase systematically which precludes attainment of satisfactory FVIII activity in patient's plasma [22-24]. For patients with anti-porcine factor VIII antibody titers $>30 \mathrm{j} . \mathrm{B} . / \mathrm{ml}$, the product may prove ineffective and it is preferable to use BPA [22-24, 27].

The frequency of FVIII activity measurements during rpFVIII therapy depends on the clinical picture, the anti-rpFVIII antibody titer and current FVIII activity in patient's plasma [27]. When 
bleeding is severe at the beginning of therapy, FVIII activity measurements may have to be performed even every 2-3 hours [2].

As already mentioned, patients who receive recombinant porcine factor VIII sometimes develop de novo inhibitors against rpFVIII at a loss of treatment response. Periodic monitoring of antirpFVIII antibody titer may therefore be warranted. In clinical practice, the appearance of anti-rpFVIII antibodies is manifested by a decrease in FVIII activity in plasma [27].

Laboratory monitoring of rpFVIII therapy enables precise dose selection with benefit for treatment efficacy, reduction of the risk of potential thrombotic complications and economy of drug consumption. Some experts therefore recommend rpFVIII concentrate as first-line treatment in AHA $[3,9]$. It must be kept in mind however that determination/detection of antibodies directed against rpFVIII takes time, so for heavy bleeding patients requiring immediate intervention BPAs are first choice drugs [27].

In Poland, rpFVIII concentrates are not reimbursed, therefore BPA is still considered first line therapy. The "National Program for the Treatment of Patients with Hemophilia and Related Hemorrhagic Diseases for 2019-2023" offers the chance of financing rpFVIII therapy, but up to date the drug has not been purchased.

Management of bleeding in AHA can be supported by transexamic acid (TxA) which has antifibrinolytic properties (Table 3 ). It can safely be used with rFVIIa, rpFVIII as well as aPCC $[2,3,9]$. For many years the combined approach (TxA and $\mathrm{aPCC}$ ) has raised safety concerns of increased risk of thromboembolic complications. Currently, numerous reports confirm the safety of these two medications used in combination [28-30]. Transexamic acid is commonly used for mucosal bleeding, but it is contraindicated in patients with severe renal impairment for risk of mechanical anuria due to clot formation $[1,2]$. An adult dose of TxA is $1 \mathrm{~g}$ every 8 hours applied either orally or intravenously. It can also be used as mouthwash [2].

\section{Inhibitor eradication in AHA patients}

The major goal in AHA management is to achieve remission, i.e. to eradicate FVIII inhibitor with immunosuppressive therapy. Partial AHA remission is defined as no active bleeding and no need for hemostatic treatment for over 24 hours, with FVIII activity above $50 \mathrm{IU} / \mathrm{dl}$ [9]. Complete remission is defined as meeting criteria for partial remission as well as negative inhibitor titer [9]. According to Holstein et al. [31] partial remission in a AHA patient significantly reduces the risk of recurrent bleeding.

Immunosuppressive therapy for eradication of FVIII inhibitor should be launched immediately after AHA diagnosis is made $[1,2,19,32]$. Glucocorticosteroids are usually recommended, mainly prednisone in monotherapy or in combination with cyclophosphamide. Prednisone is administered at a dose of $1 \mathrm{mg} / \mathrm{kg}$ bw/day for 4 to 6 weeks; cyclophosphamide also orally at a dose of $1.5-2 \mathrm{mg} / \mathrm{kg}$ bw/day for 6 weeks $[1,2,33]$. Cyclophosphamide is not recommended for young people, especially at childbearing age $[1,2]$. According to EACH2 registry, complete remission was achieved in $80 \%$ of patients following first-line treatment with glucocorticosteroids in combination with cyclophosphamide and in $58 \%$ of patients treated with glucocorticosteroids in monotherapy. During an average of 149-day follow-up after immunosuppression (interquartile range 30-603 days), a relapse was observed in $18 \%$ of patients with remission following glucocorticosteroids in monotherapy and in $12 \%$ of patients with remission after glucocorticosteroids in combination therapy with cyclophosphamide [34].

Results of a prospective, observational GTHAH study involving 102 AHA patients demonstrated that the chance to achieve partial or complete remission depends on baseline FVIII activity [35]. With FVIII activity $<1 \mathrm{IU} / \mathrm{dl}$ at AHA diagnosis partial remission was achieved less frequently and after longer immunosuppression than with baseline FVIII activity $\geq 1 \mathrm{IU} / \mathrm{dl}$. Likewise, complete remission was less frequently achieved with baseline FVIII activity $<1 \mathrm{IU} / \mathrm{dl}$ and World Health Organization Preformance Status (WHO-PS) $>2$. The impact of general health on remission rate may be explained by the fact that in the group of WHO-PS $>2$ patients more deaths occurred before complete remission was achieved [35].

According to Vautier et al. [36], the activity of FVIII $\geq 1 \mathrm{IU} / \mathrm{ml}$ and the inhibitor titer $<20 \mathrm{IU} / \mathrm{ml}$ at AHA diagnosis predicted better response to glucocorticosteroid monotherapy. The results of the GTH-AH study are similar [34]. Therefore, in patients with baseline FVIII activity $\geq 1 \mathrm{IU} / \mathrm{dl}$ and inhibitor titer $\leq 20 \mathrm{IU} / \mathrm{ml}$, it is recommended to begin immunosuppression with glucocorticosteroids in monotherapy [3, 35, 36].

AHA patients are at risk of severe bleeding until the inhibitor is eradicated. If no remission is reported after 6 -week first-line immunosuppression, a second-line eradication therapy is recommended. 
Most experts suggest/recommend rituximab, an anti-CD20 monoclonal antibody applied intravenously at a dose of $375 \mathrm{mg} / \mathrm{m}^{2}$ once weekly for 4 weeks. According to some experts, a dose of $100 \mathrm{mg} / \mathrm{m}^{2}$ once a week may also prove effective $[2,9,10,18,33,37]$. EACH2 registry reports complete remission in $61 \%$ of patients treated with rituximab as first line therapy (either in monotherapy or in combination with other immunosuppressants) and in $50 \%$ of patients treated with rituximab as second line therapy [34]. Reimbursement of rituximab by the Polish National Health Fund does not include its use in the management of AHA. It is however possible to apply for financing of rituximab as rescue therapy.

The second and subsequent lines of AHA management include also cyclosporine, azathioprine, mycophenolate mofetil and vinca alkaloids [1-3]. Concomitant use of immunosuppressants and intravenous injections of human FVIII concentrate may contribute to rapid inhibitor eradication. According to treatment guidelines developed by Hungarian authors (the so-called Budapest protocol) there is an appropriate order of applying human FVIII concentrate, cyclophosphamide and methylprednisolone $[2,38]$. On the other hand, the Bonn-Malmö program recommends using human FVIII concentrate in combination with extracorporeal immunoadsorption procedures, intravenous immunoglobulins and immunosuppression (glucocorticosteroids, cyclophosphamide) [39]. The Tiede et al guidelines [3] published in 2020 recommend this therapy only for severely bleeding patients unresponsive to other therapies. In Poland, like in most European countries (with the exception of Germany and Sweden) extracorporeal immunoadsorption is not used for AHA therapy. Intravenous immunoglobulins in monotherapy are not effective for AHA management, as confirmed by EACH 2 registry and the UKHCDO study $[4,5]$.

Immunosuppressive therapy is associated with adverse reactions in approximately 37\% of AHA patients [18]. The most common symptoms are leukopenia, thrombocytopenia, steroid diabetes and mental disorders [18]. The most serious complications of immunosuppression are however infections, which may prove fatal. According to EACH2 registry, immunosuppression-related reactions/ /complications were responsible for $4.2 \%$ of deaths (vs. $4.5 \%$ of patients whose death was attributed to bleeding) [4]. According to the SACHA registry, $12 \%$ of patients died of infectious complications, and only $3.5 \%$ from bleeding [40]; according to the
GTH-AH study, the respective data were $16 \%$ and $2.9 \%$ [31].

It is estimated that relapse is reported in approximately $10-20 \%$ of AHA patients who achieved remission with first-line immunosuppression [37]. This group should therefore remain under special care of hematological outpatient clinic for at least 2 years. It is recommended to control FVIII activity once a month for the first six months of remission, then every 2-3 months for the next six months, followed by checks every 6 months for the next year $[2,37]$.

Once AHA recurs, another attempt is made at inhibitor eradication with immunosuppressive medication listed above. The same regimen might be used that resulted in the first remission. Sometimes eradication of the inhibitor is unsuccessful despite numerous attempts at immunosuppression and patients must remain under observation [2]. If severe bleeding persists, long-term aPCC prophylaxis is considered $[2,19]$.

Prognosis in AHA depends on the type and course of comorbidities, bleeding intensity as well as accuracy and promptness of diagnosis $[1,2]$. The survival analysis in the EACH2 registry covered 331 patients, at median follow-up 248 days (interquartile range 74-685 days). Overall survival was estimated at $61.2 \%, 27.9 \%$ of patients died; the fate of $10.9 \%$ of patients remained unknown. The most common death-cause was the underlying disease (responsible for $45 \%$ of fatalities). The registry data revealed the following independent death risk factors: advanced age, lower hemoglobin concentration at AHA diagnosis, coexistence of neoplastic disease and failure to eradicate the inhibitor [4].

In the GTH-AH study, $23 \%$ of patients died within the follow-up period of 262 days (interquartile range 87-612) mostly from infections $(47 \%)$ and cardiovascular diseases (17.6\%), less frequently from bleeding ( $8.8 \%$ ) and co-morbidities $(8.8 \%)$. The study demonstrated that the baseline FVIII activity $<1 \mathrm{IU} / \mathrm{dl}$, WHO-PS $>2$ and the underlying neoplastic disorder were independent risk factors for mortality rate [35].

\section{Summary}

Acquired haemophilia A is primarily characterized by severe bleeding episodes. Oligosymptomatic or asymptomatic forms are less frequent and diagnosed accidentally when isolated prolonged APTT is detected. Latent symptoms make prompt and correct diagnosis difficult and any delay may lead to severe hemorrhagic complications that put 
the patient's health and life at risk. AHA patients should be treated by teams of specialists experienced in management of severe bleeding disorders, in haemophilia treatment centres with appropriate laboratory facilities and access to hemostatic drugs. Lately, in addition to bypassing agents, in use is also recombinant porcine factor VIII concentrate. For eradication of FVIII inhibitor in AHA patients, corticosteroids are still first- choice medication in monotherapy or in combination with cyclophosphamide. If FVIII inhibitor eradication fails with first-line treatment, the application of rituximab should be considered.

\section{References}

1. Windyga J, Chojnowski K, Klukowska A, et al. W imieniu Grupy Roboczej ds. Hemostazy Polskiego Towarzystwa Hematologów i Transfuzjologów: Polskie zalecenia postępowania w nabytej hemofilii A. Med. Prakt. 2011; 10: 42-51.

2. Windyga J, Baran B, Odnoczko E, et al. Wytyczne postępowania w nabytej hemofilii A. Gin. Perinat. Prak. 2018; 3(4): 175-188.

3. Tiede A, Collins P, Knoebl P, et al. International recommendations on the diagnosis and treatment of acquired hemophilia A. Haematologica. 2020; 105(7): 1791-1801, doi: 10.3324/haematol.2019.230771, indexed in Pubmed: 32381574.

4. Knoebl P, Marco P, Baudo F, et al. EACH2 Registry Contributors. Demographic and clinical data in acquired hemophilia A: results from the European Acquired Haemophilia Registry (EACH2). J Thromb Haemost. 2012; 10(4): 622-631, doi: 10.1111/j.1538-7836.2012.04654.x, indexed in Pubmed: 22321904.

5. Collins PW, Hirsch S, Baglin TP, et al. UK Haemophilia Centre Doctors' Organisation. Acquired hemophilia A in the United Kingdom: a 2-year national surveillance study by the United Kingdom Haemophilia Centre Doctors' Organisation. Blood. 2007; 109(5): 1870-1877, doi: 10.1182/blood-2006-06-029850, indexed in Pubmed: 17047148.

6. Baudo F, Mostarda G, de Cataldo F. Acquired factor VIII inhibitors in pregnancy: data from the Italian Haemophilia Register relevant to clinical practice. BJOG: An International Journal of Obstetrics and Gynaecology. 2003; 110(3): 311-314, doi: 10.1046/j.1471-0528.2003.01535.x.

7. Franchini M, Zaffanello M, Lippi G. Acquired hemophilia in pediatrics: a systematic review. Pediatr Blood Cancer. 2010; 55(4): 606-611, doi: 10.1002/pbc.22657, indexed in Pubmed: 20589621.

8. Windyga J, Zdziarska J, Chojnowski K, et al. Acquired hemophilia A in Poland a report from AHA-POL registry. J Thromb Haemost 2015;13;2. ; 758: PO011-WED.

9. Kruse-Jarres R, Kempton CL, Baudo F, et al. Acquired hemophilia A: Updated review of evidence and treatment guidance. Am J Hematol. 2017; 92(7): 695-705, doi: 10.1002/ajh.24777, indexed in Pubmed: 28470674.

10. Toschi V, Baudo F. Diagnosis, laboratory aspects and management of acquired hemophilia A. Intern Emerg Med. 2010; 5(4): 325-333, doi: 10.1007/s11739-010-0380-y, indexed in Pubmed: 20407848.

11. Windyga J, Chojnowski K, Klukowska A, et al. Część II: Wytyczne postępowania w hemofilii A i B powikłanej inhibitorem czynnika VIII i IX (2 wydanie). Acta Haematol Pol. 2017; 48(3): 137-159, doi: 10.1016/j.achaem.2017.08.001.
12. Huth-Kühne A, Baudo F, Collins P, et al. International recommendations on the diagnosis and treatment of patients with acquired hemophilia A. Haematologica. 2009; 94(4): 566-575, doi: 10.3324/haematol.2008.001743, indexed in Pubmed: 19336751.

13. Baudo F, Collins P, Huth-Kuhne A, et al. Management of bleeding in acquired hemophilia A: results from the European Acquired Haemophilia (EACH2) registry. Blood. 2012; 120: 39-46, doi: 10.1182/blood-2006-06-029850, indexed in Pubmed: 17047148.

14. Sallah S. Treatment of acquired haemophilia with factor eight inhibitor bypassing activity. Haemophilia. 2004; 10(2): 169-173, doi: 10.1046/j.1365-2516.2003.00856.x, indexed in Pubmed: 14962206.

15. Borg JY, Négrier C, Durieu I, et al. FEIBHAC Study Group. FEIBA in the treatment of acquired haemophilia A: results from the prospective multicentre French ,FEIBA dans l'hémophilie A acquise' (FEIBHAC) registry. Haemophilia. 2015; 21(3): 330-337, doi: 10.1111/hae.12574, indexed in Pubmed: 25359571.

16. Tiede A, Worster A. Lessons from a systematic literature review of the effectiveness of recombinant factor VIIa in acquired haemophilia. Ann Hematol. 2018; 97(10): 1889-1901, doi: 10.1007/ s00277-018-3372-z, indexed in Pubmed: 29804265.

17. Ma AD, Kessler CM, Al-Mondhiry HAB, et al. US experience with recombinant factor VIIa for surgery and other invasive procedures in acquired haemophilia: analysis from the Hemostasis and Thrombosis Research Society Registry. Haemophilia. 2016; 22(1): e18-e24, doi: 10.1111/hae.12852, indexed in Pubmed: 26551409.

18. Knöbl P. Prevention and Management of Bleeding Episodes in Patients with Acquired Hemophilia A. Drugs. 2018; 78(18): 1861-1872, doi: 10.1007/s40265-018-1027-y, indexed in Pubmed: 30542801.

19. Árokszállási A, Rázsó K, Ilonczai P, et al. A decade-long clinical experience on the prophylactic use of activated prothrombin complex concentrate in acquired haemophilia A: a case series from a tertiary care centre. Blood Coagul Fibrinolysis. 2018; 29(3): 282-287, doi: 10.1097/MBC.0000000000000716, indexed in Pubmed: 29474202.

20. Kessler CM, Knöbl P. Acquired haemophilia: an overview for clinical practice. Eur J Haematol. 2015; 95 Suppl 81: 36-44, doi: 10.1111/ejh.12689, indexed in Pubmed: 26679396.

21. Kempton CL, Abshire TC, Deveras RA, et al. Pharmacokinetics and safety of Obi-1, arecombinant B domain-deleted porcine factor VIII, in subjects with haemophilia A. Haemophilia. 2012; 18: 798-804. , doi: 10.1177/2040620717720861, indexed in Pubmed: 29051804.

22. Kruse-Jarres R, St-Louis J, Greist A, et al. Efficacy and safety of OBI-1, an antihaemophilic factor VIII (recombinant), porcine sequence, in subjects with acquired haemophilia A. Haemophilia. 2015; 21(2): 162-170, doi: 10.1111/hae.12627, indexed in Pubmed: 25623166.

23. Tarantino MD, Cuker A, Hardesty B, et al. Recombinant porcine sequence factor VIII(rpFVIII) for acquired haemophilia A: practical clinical experience of its use in seven patients. Haemophilia 2017; 23: 25-32. , doi: 10.1111/hae.13038, indexed in Pubmed: 27704655.

24. Martin K, Kasthuri R, Mooberry MJ, et al. Lower doses of recombinant porcine factor VIII maintain excellent haemostatic efficacy. Haemophilia. 2016; 22(6): e549-e551, doi: 10.1111/ hae.13038, indexed in Pubmed: 27704655.

25. Charakterystyka Produktu Leczniczego Obizur: https://www. ema.europa.eu/en/documents/product-information/obizur-epar-product-information_pl.pdf. 
26. Burness CB, Scott LJ. Susoctocog Alfa: A Review in Acquired Haemophilia A. Drugs. 2016; 76(7): 815-821, doi: 10.1007/ s40265-016-0576-1, indexed in Pubmed: 27098420.

27. Fosbury E, Drebes A, Riddell A, et al. Review of recombinant anti-haemophilic porcine sequence factor VIII in adults with acquired haemophilia A. Ther Adv Hematol. 2017; 8(9): 263-272, doi: 10.1177/2040620717720861, indexed in Pubmed: 29051804 .

28. Windyga J, Stefanska-Windyga E, Odnoczko E, et al. Activated prothrombin complex concentrate in combination with tranexamic acid: a single centre experience for the treatment of mucosal bleeding and dental extraction in haemophilia patients with inhibitors. Haemophilia. 2016; 22(5): e465-e468, doi: 10.1111/ hae.13035, indexed in Pubmed: 27457184.

29. Pasca S, Ambaglio C, Rocino A, et al. FAIR Study Group. Combined use of antifibrinolytics and activated prothrombin complex concentrate $(\mathrm{aPCC})$ is not related to thromboembolic events in patients with acquired haemophilia A: data from FAIR Registry. J Thromb Thrombolysis. 2019; 47(1): 129-133, doi: 10.1007/ s11239-018-1750-y, indexed in Pubmed: 30267246.

30. Holmström M, Tran HTT, Holme PA. Combined treatment with APCC $\left(\right.$ FEIBA $\left.^{\circledR}\right)$ and tranexamic acid in patients with haemophilia A with inhibitors and in patients with acquired haemophilia A a two-centre experience. Haemophilia. 2012; 18(4): 544-549, doi: 10.1111/j.1365-2516.2012.02748.x, indexed in Pubmed: 22348384.

31. Holstein K, Liu X, Smith A, et al. Bleeding and response to hemostatic therapy in acquired hemophilia A: results from the GTH-AH 01/2010 study. Blood. 2020; 136(3): 279-287, doi: 10.1182/blood.2019003639, indexed in Pubmed: 32268359.

32. Franchini M, Lippi G. Acquired factor VIII inhibitors. Blood. 2008; 112(2): 250-255, doi: 10.1182/blood-2008-03-143586, indexed in Pubmed: 18463353.

33. Franchini M, Vaglio S, Marano G, et al. Acquired hemophilia A: a review of recent data and new therapeutic options. Hematology.
2017; 22(9): 514-520, doi: 10.1080/10245332.2017.1319115, indexed in Pubmed: 28441921.

34. Collins P, Baudo F, Knoebl P, et al. EACH2 registry collaborators. Immunosuppression for acquired hemophilia A: results from the European Acquired Haemophilia Registry (EACH2). Blood. 2012; 120(1): 47-55, doi: 10.1182/blood-2012-02-409185, indexed in Pubmed: 22517903.

35. Tiede A, Klamroth R, Scharf RE, et al. Prognostic factors for remission of and survival in acquired hemophilia A (AHA): results from the GTH-AH 01/2010 study. Blood. 2015; 125(7): 1091-1097, doi: 10.1182/blood-2014-07-587089, indexed in Pubmed: 25525118.

36. Vautier M, de Boysson $\mathrm{H}$, Creveuil C, et al. Influence of factor VIII level and its inhibitor titer on the therapeutic response to corticosteroids alone in the management of acquired hemophilia: A retrospective single-center study. Medicine (Baltimore). 2016; 95(48): e5232, doi: 10.1097/MD.0000000000005232, indexed in Pubmed: 27902587.

37. Charlebois J, Rivard GÉ, St-Louis J. Management of acquired hemophilia A: Review of current evidence. Transfus Apher Sci. 2018; 57(6): 717-720, doi: 10.1016/j.transci.2018.10.011, indexed in Pubmed: 30396835.

38. Nemes L, Pitlik E. New protocol for immune tolerance induction in acquired hemophilia. Haematologica. 2000; 85(10 Suppl): 64-68, indexed in Pubmed: 11187874.

39. Zeitler H, Ulrich-Merzenich G, Hess L, et al. Treatment of acquired hemophilia by the Bonn-Malmo Protocol: documentation of an in vivo immunomodulating concept. Blood. 2005; 105(6): 2287-2293, doi: 10.1182/blood-2004-05-1811, indexed in Pubmed: 15542586.

40. Borg JY, Guillet B, Le Cam-Duchez V, et al. SACHA Study Group. Outcome of acquired haemophilia in France: the prospective SACHA (Surveillance des Auto antiCorps au cours de l'Hémophilie Acquise) registry. Haemophilia. 2013; 19(4): 564-570, doi: 10.1111/hae.12138, indexed in Pubmed: 23574453. 